\title{
A democracia, o diálogo e o espaço do outro
}

Democracy, dialogue and the other spaces

Impossível escrever esse editorial sem pensar no momento cultural, social e, principalmente, político em que vivemos. Em um país marcado por tantas desigualdades sociais, que criam abismos e hiatos, que inviabilizam o diálogo, lembramos da questão do saber, poder e verdade presente na genealogia foucaultiana que extrapola o poder do Estado manifestando-se nas relações sociais que tecem toda a sociedade. Na capilaridade geográfica de nosso país podemos testemunhar a dimensão espacial do poder e sua visão ontológica organizacional.

Neste momento, propomos a reflexão acerca do povo e seu poder, ou seja, a democracia. A democracia é o regime político em que a soberania é exercida pelo povo constituído por um conjunto de cidadãos que exercem o sufrágio universal (sufrágio do latim suffragium, voto). O sufrágio universal está presente na Constituição da República Federativa do Brasil, artigo 14, capítulo IV de $1988^{1}$, onde reza que "a soberania popular será exercida pelo sufrágio universal e pelo voto direto e secreto, com valor igual para todos, e nos termos da lei, mediante: I- plebiscito; II - referendo; III - iniciativa popular”.

Para Japiassú e Marcondes $\left(2001^{2}\right)$ podemos pensar essa forma de poder de três formas: a democracia direta onde o poder é exercido pelo povo, sem intermediário; a democracia parlamentar ou representativa onde o povo delega seus poderes a um parlamento eleito ou democracia autoritária onde o povo delega a um único indivíduo, por determinado tempo, ou vitaliciamente, o conjunto de poderes.

A reflexão a respeito da democracia, e suas formas de exercício de poder, deveria ser larga e profunda levando os cidadãos para um debate rico e profícuo que produzisse frutos que fossem colhidos ao longo de nossas vidas. Desta forma, a proposta reflexiva aqui é: que tipo de democracia queremos? Uma boa resposta a essa questão é que "nós estamos ainda no

\footnotetext{
${ }^{1}$ BRASIL. Constituição (1988): constituição da república federativa do Brasil. Brasília: Senado Federal: Centro Gráfico, 1988. 292 p.

2 JAPIASSÚ, H.; MARCONDES, D. Dicionário básico de filosofia. 3. ed. ampl. rev. Rio de Janeiro: Jorge Zahar, 2001. Disponível em: 〈http://raycydio.yolasite.com/resources/dicionario_de_filosofia_japiassu.pdf $>$. Acesso em: 25 out. 2018.
}

Bibl. Esc. em R., Ribeirão Preto, v. 6, n. 1, p. i-iii, 2018.

DOI: 10.11606/issn.2238-5894.berev.2018.150853 
processo de aprender como fazer democracia. E a luta por ela passa pela luta contra todo tipo de autoritarismo" (FREIRE, 2000, 136 ${ }^{3}$ ).

As palavras de Paulo Freire reverberam... se estamos no processo de aprender democracia podemos entendê-la como um ato educativo. Ato educativo, ato de educação, ação educativa... Ação contrária à passividade, ação pela qual o indivíduo é a causa modificante de si e o do meio físico que o circunda. A democracia como ato educativo seria vista no conjunto de nossas práticas diárias de cidadãos.

Só querer o ato não é suficiente. É necessário canais de medicação para que aconteça essa práxis: a família, a escola, os grupos sociais, a universidade, os espaços institucionalizados, a sociedade civil organizada, a biblioteca, o arquivo, o museu, a praça, o jardim, a igreja, as brincadeiras infantis, os conventos, os mosteiros, os bares, as conversas com os amigos.... ou seja, todos os ambientes e espaços possíveis e imagináveis.

Mas, enquanto essa dialogismo não "é" podemos pensar na heterotopia, proposta por Foucault no texto Outros Espaços ${ }^{4}$, enquanto conceito para demonstrar o espaço do outro que foi esquecido na cultura ocidental. Afastamos o outro, a diferença, a multiplicidade. Pensar a heterotopia é resgatar como o filósofo o espaço do outro, resgatar o espaço do mesmo.

Pensar a biblioteca como uma heterotopia é o que os autores nos possibilitam neste número da revista.

Maria Isabel Soares Feitora e Maria do Carmo Caetano apresentam o artigo "Espaços e ações das Bibliotecas Escolares no âmbito do Plano de Ações Articuladas (PAR) do Município de Dourados, MS" onde analisam a condução PAR no que diz respeito a infraestrutura física e pedagógica das bibliotecas escolares da rede municipal de ensino tendo como considerações que as diversas ações resultaram na melhoria da qualidade das bibliotecas, ampliando e construindo novos espaços.

Ada Miriam Cabral e Rodrigo Pereira apresentam o artigo "Políticas públicas para a biblioteca escolar e o fortalecimento da identidade regional brasileira: as contribuições do PNBE". Artigo que trabalha com o Programa Nacional Biblioteca da Escola (PNBE) mostrando questões sobre o desenvolvimento de coleções proposto pelo programa.

\footnotetext{
${ }^{3}$ FREIRE, P. A educação na cidade. 4.ed. São Paulo: Cortez, 2000.

${ }^{4}$ FOUCAULT, M. Estética: literatura e pintura, música e cinema. 2. ed. Rio de Janeiro: Forense Universitária, 2009. Ditos e escritos III. Disponível em: <http://abdet.com.br/site/wp-content/uploads/2015/02/Ditos-e-escritosIII-Est\%C3\%A9tica.pdf> . Acesso em: 3 out. 2018.
} 
Rosemari Pereira dos Santos Alves e Rovilson José da Silva escreveram o artigo "Vlogs e o incentivo à formação de leitores" destacando o movimento transmidiático, o conteúdo on-line e os vlogs (tipo de blog onde o conteúdo predominante são vídeos). Apresentam os vlogs como um importante instrumento de incentivo à leitura podendo ser utilizado pela biblioteca escolar.

Bernadete Santos Campello e Eduardo Valadares da Silva assinam o artigo "Subsídios para esclarecimento do conceito de livro paradidático" que busca esclarecer controvérsias a cerca do conceito, demonstrando resultados interessantes e importantes sobre o termo paradidático.

Artigos que dialogam com nossa proposta de reflexão: a democracia como um ato educativo e a biblioteca uma heterotopia por excelência.

Deise Maria Antonio Sabbag

Editora 